\title{
Determinants of Adoption of Improved Cocoa Technologies in Ekiti State, Nigeria
}

\author{
Julius Olumide Ilesanmi*, Jimoh Atanda Afolabi \\ Akure, Nigeria \\ Email address: \\ olumideilesanmi@gmail.com (J. O. Ilesanmi), jaafolabi@futa.edu.ng (J. A. Afolabi) \\ ${ }^{*}$ Corresponding author
}

Department of Agricultural and Resource Economics, School of Agriculture and Agricultural Technology, Federal University of Technology,

\section{To cite this article:}

Julius Olumide Ilesanmi, Jimoh Atanda Afolabi. Determinants of Adoption of Improved Cocoa Technologies in Ekiti State, Nigeria. International Journal of Agricultural Economics. Vol. 5, No. 2, 2020, pp. 36-42. doi: 10.11648/j.ijae.20200502.11

Received: February 28, 2020; Accepted: March 17, 2020; Published: April 1, 2020

\begin{abstract}
The study investigated the determinants of adoption of improved cocoa technologies in Ekiti State, Nigeria. Specifically, it examined the socio economic characteristics of the cocoa farmers in the study area; identified the various technologies practiced by cocoa farmers in the study area and determined the intensity of adoption of improved technologies. A multi-stage sampling technique was used to select eighty (80) respondents in four (4) local government areas namely: Ise/Orun LGA, Irepodun Ifelodun LGA, Oye LGA and Ekiti South-West LGA; which were predominated with cocoa farmers. Tobit model was used to examine the determinants and intensity of adoption of improved cocoa technologies. At 5\% level of significance, variables that positively and significantly influence adoption of improved cocoa technologies include sex, level of education, source of information and visit by the extension agents; meaning they were important in the adoption of improved cocoa technologies and raises the probability of adoption by $9.14,2.97,2.98$ and 3.94\%. The age of the cocoa farmers; family size and the farm size were not significant and have negative coefficients meaning increase in these factors will reduce the likelihood of cocoa farmers adopting the improved techniques. Result of budgeting analysis implies a better performance of the adopters of improved cocoa technologies whereby the benefit cost ratio for the adopters and non-adopters of improved cocoa technologies were 3.50 and 1.26 respectively.
\end{abstract}

Keywords: Adoption, Intensity, Cocoa, Determinants, Benefit Cost Ratio, Adopters, Non-adopters, Budgeting Analysis

\section{Introduction}

Cocoa which belongs to the family Sterculiacaea and of the genus Theobroma was discovered in $18^{\text {th }}$ century at the Amazon basin and later spread to the other tropical areas of South and Central America, and West Africa [17]. Since the end of the First World War, West Africa has been the highest producer of cocoa [21]. Cocoa, being a tropical tree grown mostly in a zone that extends $15^{\circ}$ north and $15^{\circ}$ south of the equator, its largest production area has been West Africa where about 60 percent of the world's cocoa is grown [3, 19]. The four major West Africa cocoa producers are the Ivory Coast, Ghana, Nigeria and Cameroun [9]. Nigeria produced about $6 \%$ of the world's cocoa while Ghana, the second largest producer of cocoa in West Africa contributes $14 \%$ to the world's output in contrast to Ivory Coast which produces about 43 percent of the world's cocoa output [9].
Agriculture has been the backbone of the economy of Nigeria and it employs over $75 \%$ of the population. This sector has recorded the growth rate well above 5\% compared with less than $2 \%$ growth of early 80 's [6]. In Nigeria, cocoa has been the main agricultural stake of the economy until early 1970's when crude oil was discovered in commercial quantity. However, cocoa has remained a valuable crop and a major foreign exchange earner among agricultural commodity exports of the country [1-3]. Folayan, Daramola and Oguntade (2006), noted that cocoa production in Nigeria witnessed a downward trend after 1971 season, when its export declined to 216,000 metric tons in 1976 , and 150,000 metric tons in 1986, therefore reducing the country's market share to about $6 \%$ and to fifth largest producer to date.

Apart from these, due to high population pressure, farm and farmlands have become smaller and fragmented. However, population growth has outstripped agricultural output growth 
thus the issue of food security and low agricultural productivity [11]. These issues are viewed as a result of low adoption of agricultural research results and technologies that can increase farmers' productivity. The rate of adoption of technology is very low due to expected benefit or net returns that may or may not result from practice $[5,18]$.

Also, one of the challenges facing agricultural policy makers is the need for the investigation of those economic factors which contribute to the adoption of new and/or improved farm technology. For farmers to adopt an improved agricultural technology, they pass through many stages such as awareness, interest, trial, evaluation and adoption [4]. Previous work investigated that extension workers, mass media and individual contact with neighbours proved most effective determinants in the adoption process $[12,14]$.

Cocoa has helped to boost the economies of the major producing states in Nigeria [15]. Ekiti State is one of the 14 cocoa producing states in Nigeria and contributes significantly to the national cocoa output. For instance, Ondo and Ekiti States combined; accounted for about $53.32 \%$ of the total Nigeria cocoa output based on available data from 1976 to 2003 [8].

The major need for adoption of improved technologies is to increase the production level and in the end build up the economy of the country. There are many improved technologies; to mention but a few such as: cultural maintenance of farm; genetic improved seedlings; use of improved agrochemicals; fertilizer usage and applications; harvesting, fermentation and drying technologies; shade reduction, adoption of improved spacing etc [16]. All these are expected to be adopted in order to attend to the declining productivity of cocoa.

\section{Methodology}

\subsection{Study Area}

The study was conducted in Ekiti State which is one of the fourteen states that are majorly involved in cocoa production in Nigeria. Ekiti State has 16 local government areas which are: Ado, Irepodun- Ifelodun, Ijero, Efon- Alaye, Moba, Ikole, Ido-Osi, Ileje-meje, Oye, Ise/Orun, Emure, Gbonyi, Ekiti East (Omuo), Ikere, Ekiti South West and Ekiti West.

Ekiti State is located between latitudes $7^{\circ} 25^{\prime}$ and $80^{\circ} 5^{\prime} \mathrm{N}$ and between longitudes $4^{\circ} 45^{\prime}$ and $5^{\circ} 46$ east of the equator. The state is bounded to the north by Kwara and Kogi States while it is bounded by Osun State to the west. To the east of Ekiti State is found Edo State, while it is bounded in the south by Ondo State with a total land area of 5887.890sq km. Ekiti State is a landlocked state, having no coastal boundary. The Ekiti State has an estimated population of 2.40 million persons [13]. Moreover, the land is buoyant in agricultural resources with cocoa as its leading cash crop. It was largely known that Ekiti State contributed well over $40 \%$ of the cocoa products of the famous old Western Region [20]. The state is also known for its forest resources, notably timber. Because of the favourable climatic conditions, the land enjoys luxuriant vegetation, thus, it has abundant resources of different species of timber. Food crops like yam, cassava and grains like rice and maize are grown in large quantities. Other notable crops like kola nut and varieties of fruits are also cultivated in commercial quantities [20].

\subsection{Sampling Technique}

The technique of sampling used for the study was Multi-stage; in which four Local Government Areas (LGAs) which are predominated with cocoa farmers were selected for the study. At the first stage, Ekiti State was selected because it is one of the fourteen states involved in cocoa production in Nigeria. At the second stage four LGAs were selected out of the sixteen LGAs in Ekiti state and these are: Ise/Orun; Oye; Irepodun-Ifelodun and Ekiti South West using structured questionnaire coupled with schedule interview to collect data. At the third stage, a random sampling of 4 to 8 villages within the LGAs selected based on their involvement in cocoa production and random selection of twenty respondents from each LGA to give a total of eighty respondents from the study area.

Primary data were used for this study. Primary data relating to personal, socioeconomic, adoption variables and other relevant issues were collected. The data were collected using quantitative approach by means of household and one-on-one contact survey.

Descriptive statistics mainly frequency, percentage, mean, median and standard deviation was used to analyze the socioeconomic attributes of the cocoa farmers in the study area. The Tobit model was employed to identify the determinants of the technology package adoption and analyze farmers' probability of technology adoption and the intensity of adoption. Budgetary analysis (gross margin) was set up to indicate the performance of the farm and revealed benefit cost ratios of the adopters and non-adopters of the technologies.

\subsubsection{Determination of Intensity}

For multiple practices (package), there are two options of measuring adoption; (i) adoption index: measures the extent of adoption at the time of the survey or (ii) adoption quotient: measures the degree or extent of use with reference to the optimum possible without taking time into consideration. In this study, the first option will be employed. Accordingly, adoption index which shows to what extent the respondent farmer has adopted the whole set of package will be calculated using weights. In order to know the intensity of adoption of cocoa improved technologies, first we are to list the technologies or package with experts and model farmers. And based on the weight of all the adopter and non-adopters respondents, intensity of adoption is going to be calculated. The weights are shared based on the frequent usage of the technologies among farmers. 
Table 1. Types of improved technologies and its' share weight in total intensity of adoption of the technologies and rating methods.

\begin{tabular}{|c|c|c|c|}
\hline $\mathbf{S} / \mathbf{N}$ & Types of Improved Technologies & Weights & Methods of Rating \\
\hline 1 & Fertilizer Usage/Application & 0.2 & $\begin{array}{l}\text { (Organic \& Inorganic Fertilizer) } \\
\text { Used only } 1=0.05 ; \text { used } 1 \mathrm{WRA}=0.1 ; \text { both } \mathrm{WNRA}=0.15 ; \text { both } \mathrm{WRA}=0.2 ; \text { No }=0 .\end{array}$ \\
\hline 2 & Improved genetic seedlings & 0.1 & Part planting $=0.05 ;$ fully planted $=0.1 ; \mathrm{No}=0$. \\
\hline 3 & Use of fungicides and insecticides & 0.2 & 1 time $=0.025 ; 2$ times $=0.05 ; 3=0.075 ; 4=0.1 ;>4=0.2 ; \mathrm{No}=0$ \\
\hline 4 & Cultural maintenance practices & 0.2 & $\begin{array}{l}\text { Shade reduction, spacing, pruning, regular weeding etc. Used } 1 \text { method }=0.025 ; 2 \\
\text { methods }=0.05 ; 3=0.075 ; 4=0.1 ;>4=0.2 ; \mathrm{No}=0\end{array}$ \\
\hline 5 & Use of mechanized equipments/tools & 0.1 & Used at least $2=0.025 ; 3=0.05 ; 4=0.075 ;>4=0.1 ; \mathrm{No}=0$ \\
\hline 6 & Cutting of the old cocoa trees & 0.1 & Part cutting $=0.05 ;$ full cutting $=0.1 ; \mathrm{No}=0$ \\
\hline 7 & Post harvesting improved technologies & 0.1 & Employed only 1 technique $=0.025 ; 2=0.05 ; 3=0.075 ; \geq 4=0.1$ \\
\hline \multicolumn{2}{|c|}{ Total Intensity of Adoption } & 1.0 & \\
\hline
\end{tabular}

Source: Computed by the author

WRA - With Recommended Application WNRA - With No Recommended Application

\subsubsection{The Tobit Model}

The Logit and the Probit models are most common models used by various studies in assessing the effects of factors influencing the probability of adoption of a given technology. However, adoption studies based upon dichotomous regression models have attempted to explain only the probability of adoption versus non - adoption rather than the rate and the intensity of adoption. The knowledge that farmer is using improved genetic seedlings may not provide adequate information about farmers behaviours towards adoption as the farmer may be using $1 \%$ or $100 \%$ of his/her farm for the new improved technologies. Also, in the case of fertilizer adoption, a farmer may be using small quantities or large amount of fertilizer per unit area of land. Hence, a strictly dichotomous variable often is not sufficient for examining the extent and intensity of adoption for some problems such as fertilizer [7]. Tobit model is also a broad class of model that has both discrete and continuous parts. It is an extension of the Probit model and it is really one approach to dealing with the problem of censored data [10].

\subsubsection{Specification of the Tobit Model}

The Tobit model applied for analyzing determinants of adoption of improved cocoa technologies is shown below:

$$
\mathrm{Yi}^{*}=\beta \mathrm{Xi}+\mu \mathrm{i}, \mathrm{i}=1,2 \ldots \mathrm{n} .
$$

Where,

$\mathrm{Yi}=$ the observed dependent variable (index of adoption of improved technologies)

$\mathrm{Yi}^{*}=$ the latent variable which is not observable

$\mathrm{Xi}=$ vector of factors affecting adoption and intensity of improved technologies

$\beta \mathrm{i}=$ vector of unknown parameters

$\mu \mathrm{i}=$ residuals that are independently and normally distributed with mean Zero and a common variance $(\sigma 2)$.

The Tobit model shown above is also called a censored regression model because it is possible to view the problem as one where observation of $\mathrm{Y}^{*}$ at or below zero are censored [10].

\subsection{Definition of Variables}

\subsubsection{Dependent Variables}

The dependent variable in this study is Adoption Index (AI) which indicates respondent farmers' adoption and intensity of adoption to cocoa technologies. Adoption index is one of the techniques that are used in the case of adoption study of multiple practices (package) and measures adoption and intensity of adoption of improved cocoa technologies. Adoption index in this case is a continuous dependent variable (Yi). The dependent variable was zero for non-adopters and varied between 0 and 1 for adopters (where 1 mean $100 \%$ of cocoa improved technologies were adopted).

\subsubsection{Independent Variables or Explanatory Variables}

The explanatory variables of importance in this study are those variables, which are thought to have influence on adoption and intensity of adoption of cocoa technologies. These include personal and socio-economic characteristics, technical and institutional variables $(\mathrm{Xi})$ :

$\mathrm{X}_{1}=$ Age of the farmer (Years)

$\mathrm{X}_{2}=$ Educational Status of the farmer

$\mathrm{X}_{3}=$ Sex of the farmer

$\mathrm{X}_{4}=$ Household Size

$\mathrm{X}_{5}=$ Area of Land Cultivated (Ha)

$\mathrm{X}_{6}=$ Sources of Information

$\mathrm{X}_{7}=$ Visit by the Extension Agent

$\mathrm{X}_{8}=$ Cooperative Membership

$\mathrm{X}_{9}=$ Amount and Use of credit ( $\left.\mathbb{N}\right)$

$\mathrm{X}_{10}=$ Cost of Adoption ( $)$

A budget is the quantitative expression of total farm plan; summarizing the income, cost and profit (a residue of total cost from total revenue). A total farm budget approach was undertaken to estimate costs and returns accruing to each farmer. Gross margin which is the difference between the total revenue and total variable cost were analyzed. The total cost component is expressed as:

$$
\mathrm{TC}=\mathrm{TFC}+\mathrm{TVC}
$$

Where: $\mathrm{TC}=$ Total Cost; $\mathrm{TFC}=$ Total Fixed Cost; $\mathrm{TVC}=$ Total Variable Cost

$\mathrm{TR}=$ Price $(\mathrm{P}) \times$ Quantity (Q) that is, PQ

Where: $\mathrm{TR}=$ Total Revenue

Gross Margin = TR $-\mathrm{VC}$;

Where: $\mathrm{VC}=$ Variable Cost

Profit $=\mathrm{TR}-\mathrm{TC}$

The efficiency ratio that were analyzed are fixed cost ratio, rate 
of returns, variable to cost ratio, benefit cost ratio amongst others. These were computed to indicate the performance of the farm.

\section{Results and Discussion}

\subsection{Socio Economics Characteristics of the Farmers}

The result from Table 2 showed that most of the respondents were adults whose age ranged between 30 and 59 years $(53.75 \%)$. Also, the males were preponderant and constituted about 7 out of 10 in the study area. Findings showed that $68.75 \%$ of the respondents were married while $13.75 \%$ were singles. About $18.75 \%$ of the respondents have undergone university education while $53.75 \%$ of the respondents have no formal education. Also, 21.3\% of the farmers have family size range between 7 and 9; which have certainly helped in their cocoa production comparing to a situation of hiring labour on farms. Inherited cocoa farms $(90.0 \%)$ are most predominant among the respondents and $20.00 \%$ of the respondents have their farms ranging between 20 and 29 hectares. Also, It can be observed from the study that $27.50 \%$ of respondents got information about cocoa improved technologies from extension agents and most of the respondents $(32.50 \%)$ got information from their neighbours (friends and family). Cost of adoption of the improved cocoa technologies was so high with most of the farmers emphasizing on this. $46.25 \%$ declare the cost of adoption to be moderately high. In sum, $95 \%$ of the respondents' perceived cost of adopting all the improved cocoa technologies was high while only $5 \%$ is quite indecisive of the adoption cost.

\subsection{Determinants of Adoption of Improved Cocoa Technologies Among Farmers in the Study Area}

The result from the Tobit regression in Table 3 indicated that half of the variables affect the probability of adoption as expected. Variables that positively and significantly influence adoption of improved cocoa technologies include sex, level of education, source of information and visit by the extension agents. An increase in the education of cocoa farmers raises the probability of adoption by $2.97 \%$. Similarly, increasing the visit by the extension agents increases the probability of adoption of improved cocoa technologies by $3.94 \%$. Likewise, increasing information sources on adoption of improved technologies by one degree increases the probability and the intensity of adopting new innovation by $2.98 \%$.

Farm size, household size and age were negatively related to adoption. The probable reason for the negative relationship between adoption and farm size could be because the adoption is specifically based on intensity. This means that it is not the size of the farm but the specific improved technologies adopted on the farms and intensity of adoption. Thus, future research could reveal more information about factors dictating adoption at farm or plot level. Moreover, the probable reason for the negative relationship between household size and adoption of improved cocoa technologies could be due to the fact that, increase in the household size will subject constraints to adoption as regard distribution of income. The age of the farmers has negative influence on adoption as increase in the age of the farmers by one year will reduce the likelihood of adopting improved cocoa technologies. This could be due to the fact that close to half of the farmers are aged.

Likewise, factor that is believed to create awareness such as cooperative membership and factor that encourages adoption such as amount of credit increase the likelihood of adoption of improved cocoa technologies by 3.75 and $0.082 \%$ respectively.

Table 2. Socio Economic Characteristics of the Cocoa Farmers.

\begin{tabular}{|c|c|c|c|c|c|c|}
\hline \multirow{2}{*}{ Characteristics } & \multicolumn{2}{|l|}{ Adopters } & \multicolumn{2}{|c|}{ Non-Adopters } & \multicolumn{2}{|l|}{ Total } \\
\hline & Frequency & Percentage & Frequency & Percentage & Frequency & Percentage \\
\hline \multicolumn{7}{|l|}{ Age Range (Years) } \\
\hline$<30$ Years & 6 & 16.67 & 3 & 6.81 & 9 & 11.25 \\
\hline $30-39$ Years & 4 & 11.11 & 11 & 25.00 & 15 & 18.75 \\
\hline $40-49$ Years & 7 & 19.44 & 10 & 22.73 & 17 & 21.25 \\
\hline $50-59$ Years & 5 & 13.89 & 6 & 13.64 & 11 & 13.75 \\
\hline 60 years above & 14 & 38.89 & 14 & 31.82 & 28 & 35.00 \\
\hline \multicolumn{7}{|l|}{ Sex of Respondents } \\
\hline Male & 28 & 77.78 & 31 & 70.45 & 59 & 73.75 \\
\hline Female & 8 & 22.22 & 13 & 29.55 & 21 & 26.25 \\
\hline \multicolumn{7}{|l|}{ Marital Status } \\
\hline Singles & 5 & 13.89 & 6 & 13.64 & 11 & 13.75 \\
\hline Married & 25 & 69.44 & 30 & 68.18 & 55 & 68.75 \\
\hline Widowed & 6 & 16.67 & 7 & 15.91 & 13 & 16.25 \\
\hline Divorced & 0 & 0 & 1 & 2.27 & 1 & 1.25 \\
\hline \multicolumn{7}{|l|}{ Educational Status } \\
\hline No Formal Education & 21 & 58.33 & 22 & 50.00 & 43 & 53.75 \\
\hline Primary Education & 3 & 8.33 & 5 & 11.36 & 8 & 10.00 \\
\hline Secondary Education & 5 & 13.89 & 8 & 18.18 & 13 & 16.25 \\
\hline University Education & 7 & 19.44 & 8 & 18.18 & 15 & 18.75 \\
\hline Others (Quaranic) & 0 & 0 & 1 & 2.27 & 1 & 1.25 \\
\hline \multicolumn{7}{|l|}{ Family Size } \\
\hline $1-3$ & 6 & 16.67 & 10 & 22.73 & 16 & 20.00 \\
\hline $4-6$ & 16 & 44.44 & 18 & 40.91 & 34 & 42.50 \\
\hline
\end{tabular}




\begin{tabular}{|c|c|c|c|c|c|c|}
\hline \multirow{2}{*}{ Characteristics } & \multicolumn{2}{|l|}{ Adopters } & \multicolumn{2}{|c|}{ Non-Adopters } & \multicolumn{2}{|l|}{ Total } \\
\hline & Frequency & Percentage & Frequency & Percentage & Frequency & Percentage \\
\hline $7-9$ & 8 & 22.22 & 9 & 20.45 & 17 & 21.25 \\
\hline 10 above & 6 & 16.67 & 7 & 15.91 & 13 & 16.25 \\
\hline \multicolumn{7}{|c|}{ Mode of Farm Acquaintance } \\
\hline Inherited & 33 & 91.67 & 39 & 88.64 & 72 & 90.00 \\
\hline Rented & 1 & 2.78 & 2 & 4.55 & 3 & 3.75 \\
\hline Purchased & 2 & 5.56 & 3 & 6.82 & 5 & 6.25 \\
\hline \multicolumn{7}{|l|}{ Farm Size $(\mathrm{Ha})$} \\
\hline $1-9$ & 11 & 30.56 & 13 & 29.55 & 24 & 30.00 \\
\hline $10-19$ & 15 & 41.67 & 16 & 36.36 & 31 & 38.75 \\
\hline $20-29$ & 6 & 16.67 & 10 & 22.73 & 16 & 20.00 \\
\hline $30-39$ & 2 & 5.56 & 4 & 9.09 & 6 & 7.50 \\
\hline 40 above & 2 & 5.56 & 1 & 2.27 & 3 & 3.75 \\
\hline \multicolumn{7}{|c|}{ Source of Information } \\
\hline Extension agent & 11 & 30.56 & 11 & 25.00 & 22 & 27.50 \\
\hline Neighbours & 10 & 27.78 & 16 & 36.36 & 26 & 32.50 \\
\hline Association & 6 & 16.67 & 7 & 15.91 & 13 & 16.25 \\
\hline Radio & 9 & 25.00 & 10 & 22.73 & 19 & 23.75 \\
\hline \multicolumn{7}{|l|}{ Cost of Adoption } \\
\hline Very High & 14 & 38.89 & 25 & 56.82 & 39 & 48.75 \\
\hline High & 21 & 58.33 & 16 & 36.36 & 37 & 46.25 \\
\hline Undecided & 1 & 2.78 & 3 & 6.82 & 4 & 5.00 \\
\hline
\end{tabular}

Source: Computed from field survey, 2012.

Table 3. Coefficients.

\begin{tabular}{lllll}
\hline \multirow{2}{*}{ Explanatory Variables } & Tobit Regression Model & & Marginal Effects & Coefficients \\
\cline { 2 - 5 } & Coefficients & P-Value & 0.2135212 & 0.000 \\
\hline Constant & 0.4265185 & 0.000 & -0.0026331 & 0.899 \\
Age $\left(\mathrm{X}_{1}\right)$ & -0.0061711 & 0.911 & 0.0914157 & 0.000 \\
Sex $\left(\mathrm{X}_{2}\right)$ & $0.1921396^{*}$ & 0.000 & 0.0297813 & 0.000 \\
Level of education $\left(\mathrm{X}_{3}\right)$ & $0.0766397^{*}$ & 0.000 & -0.010253 & 0.311 \\
Family size $\left(\mathrm{X}_{4}\right)$ & -0.0331239 & 0.141 & -0.000989 & 0.297 \\
Area of land in ha $\left(\mathrm{X}_{5}\right)$ & -0.003173 & 0.312 & 0.0298121 & 0.011 \\
Source of information $\left(\mathrm{X}_{6}\right)$ & $0.068703^{*}$ & 0.010 & 0.0394110 & 0.011 \\
Visit by extension agent $\left(\mathrm{X}_{7}\right)$ & $0.0875135^{*}$ & 0.019 & 0.0375621 & 0.410 \\
Cooperative membership $(\mathrm{X} 8)$ & 0.0500953 & 0.309 & 0.0008215 & 0.133 \\
Amount of credit $\left(\mathrm{X}_{9}\right)$ & 0.001097 & 0.143 & -0.004721 & 0.004 \\
Cost of adoption $\left(\mathrm{X}_{10}\right)$ & $-0.0095363 *$ & 0.003 & & \\
\hline
\end{tabular}

*Significant at 5\% level of significance

Source: Computed from field survey, 2012.

\subsection{Rate of Adopting Improved Cocoa Technologies}

The result of the rate of adopting improved cocoa technologies shown in Table 4 reveals the ranking order of the identified technologies by the respondents throughout the study areas and the level of adoption. Most of the farmers identified cultural maintenance practices to be the best improved technology one can adopt to improve and increase cocoa production. About $21.1 \%$ of the respondents said that cultural maintenance practice is the best technology a farmer can adopt to improve cocoa production. The use of improved fungicides and insecticides is ranked second among the respondents as a technology a farmer can adopt in improving cocoa production and about $19.5 \%$ of the respondents admit this as one of the best way one can achieve a tangible production result at the end of the cocoa season. Further, $17.40 \%$ ranked fertilizer usage and application third among the improved technologies. Improved post harvesting equipments and techniques were ranked fourth with $11.60 \%$ of the respondents while only $10.60 \%$ of the respondents agree that cutting of old cocoa trees to plant the new improved seedlings is adoptable by them. It could be observed that virtually half of the respondents attributed reduction in income; production risk; unsure benefits and high cost of adoption as reasons for not fully adopting the technology due to land fragmentation and unsure compensating value gained in the process. The use of improved mechanized equipments and tools such as sprayer, pruning saw, mower and harvester tools was ranked least by the respondents suggesting that few of the farmers are conversant with the usage of these implements. However, $90.2 \%$ of the respondents felt that the usage of their old implement was the best for carrying out their production. Only $10.0 \%$ of the respondent farmers identified improved genetic seedlings technology to have been adopted and it was ranked sixth among the improved cocoa technologies while $90.0 \%$ attributed unavailability of the seedlings and inadequate farm land as factors for not adopting the 
technology.

Table 4. Rate of Adoption of the Improved Cocoa Technologies.

\begin{tabular}{lll}
\hline Identified Improved Technologies & Frequency & Percentage \\
\hline Fertilizer Usage/Application & 66 & 17.40 \\
Improved genetic seedlings & 38 & 10.00 \\
Use of fungicides and insecticides & 74 & 19.50 \\
Cultural maintenance practices & 80 & 21.10 \\
Machineries & 37 & 9.80 \\
Cutting of the old cocoa trees & 40 & 10.60 \\
Post harvesting improved technologies & 44 & 11.60 \\
\hline
\end{tabular}

Source: Computed from field survey, 2012.

\subsection{Effect of the Adoption of Improved Cocoa Technologies on Farmers' Income in the Study Area}

Result of budgeting analysis revealed that the proportion of costs varied for adopters and non-adopters as shown in Table 5. The proportion of cocoa improved seedlings for the adopters and non-adopters are $\$ 29184.21$ and $\$ 34357.14$ which accounted for $7.65 \%$ and $9.00 \%$ of the total cost respectively while that of labour cost are $\$ 27326.98$ and $\$ 4879.63$ which accounted for $7.16 \%$ and $1.28 \%$ of the total cost for adopters and non- adopters respectively. Cost of fertilizer and cultural maintenance practice for the adopters are $\$ 1620.88$ and $\$ 39860.89$ and that of the non-adopters are $\$ 1530.21$ and $\$ 13876.00$ showing $0.43 \%$ and $10.44 \%$ of the total cost for the adopters; and $0.40 \%$, and $3.64 \%$ of the total cost for the non-adopters respectively. Fungicides and insecticides cost for both the adopters and non-adopters were $\$ 7445.67$ and $\$ 5784.26$, which accounted for $1.95 \%$ and $1.52 \%$ of the total cost of production while costs of harvesting, which are 56347.77 and 25657.44 for the adopters, and non- adopters respectively accounted for $14.76 \%$ and $6.72 \%$ of the total cost. The storage cost was the lowest and this could be to the fact that larger percentage of the farmers does not use storage facilities. Transportation cost of the farmers for the both the adopters an non-adopters was $\$ 45768$ and 2897 respectively; these accounted for $11.99 \%$ and $0.76 \%$ of the total cost of production.

Average total revenue for adopters was $\$ 1335100$ while that of non-adopters was $\$ 313800$. The total variable cost for adopters and non-adopters were $\$ 208100.85$ and $\$ 89110.03$ respectively. Gross margin values were 1126999.15 and \#224689.97 for adopters and non-adopters respectively. The result implies a better performance of the adopters of improved cocoa technologies. Moreover, the average yield per hectare for the adopters was $330000 \mathrm{~kg}$ and $108671 \mathrm{~kg}$. The benefit cost ratio for the adopters and non-adopters of improved cocoa technologies were 3.50 and 1.26 respectively; showing better returns due to adoption of improved cocoa technologies.

Table 5. Budgetary analysis per hectare of cocoa farmers in the study area.

\begin{tabular}{|c|c|c|}
\hline \multirow{2}{*}{ Costs } & \multirow{2}{*}{ Adopters } & \multirow{2}{*}{ Non-Adopters } \\
\hline & & \\
\hline Cocoa improved seedling ( () & 29184.21 & 34357.14 \\
\hline Labour cost ( & 27326.98 & 4879.63 \\
\hline Fertilizer cost ( () & 1620.88 & 1530.21 \\
\hline Fungicides and Insecticides (\#) & 7445.67 & 5784.26 \\
\hline Cultural maintenance practice (\#) & 39860.89 & 13876.00 \\
\hline Harvesting ( & 56347.77 & 25657.44 \\
\hline Storage ( & 546.45 & 128.35 \\
\hline Transportation (\#) & 45768 & 2897 \\
\hline Total Variable Cost (\#) & 208100.85 & 89110.03 \\
\hline \multicolumn{3}{|l|}{ B: Fixed Costs } \\
\hline Implements costs ( & 10674.29 & 7540 \\
\hline Land Cost (\#) & 162884.62 & 153214.29 \\
\hline Total Fixed Cost (®) & 173558.91 & 160754.29 \\
\hline Total Cost ( & 381659.76 & 249864.32 \\
\hline Yield (Kg) & 330000 & 108671 \\
\hline Revenue ( & 1335100 & 313800 \\
\hline Gross Margin (®) & 1126999.15 & 224689.97 \\
\hline Net Revenue (®) & 953440.24 & 63935.68 \\
\hline Benefit cost ratio (BCR) & 3.50 & 1.26 \\
\hline
\end{tabular}

Source: Computed from field survey, 2012.

\section{Conclusions}

It can be concluded that $11.51 \%$ of the farmers in Ekiti State perceived that adopting all the improved technologies will improve production of cocoa (*multiple response exist) while others have adopted one or more elements of the technology. The source of information, constant visit by extension agents, level of education and the involvement of working class youths in cocoa production are factors that contributed mainly to the adoption of improved cocoa technologies. There is a better performance for the adopters of improved cocoa technologies as the findings showed the average yield per hectare between the adopters and non-adopters to be $330000 \mathrm{~kg}$ and $108671 \mathrm{~kg}$ respectively; while the gross margin values were $\$ 1126999.15$ and $\$ 224689.97$ for the adopters and non- adopters respectively. The benefit cost ratio for the adopters and non-adopters of improved cocoa technologies were 3.50 and 1.26 respectively; showing better returns due to adoption of improved cocoa technologies. It is quite obvious 
that adopting all the improved cocoa technologies will increase production and thereafter increase the net annual income of the cocoa farmers and improve their standard of living as well.

\section{Recommendations}

Based on the findings of this study, Farmers should be encouraged to improve their level of education through the adult literacy programs and this is quite important in as much as level of education was found to have affected the adoption of improved cocoa technologies. Government should increase access of the cocoa farmers to funds and acquirable loans with soft policies to allow them to be financially equipped in order to purchase the inputs needed to harness improved cocoa technologies. Encouragement should be given to the Agricultural NGOs, Input dealers, Extension agents, Agricultural professionals and Researchers by the government so as to get closer to cocoa farmers and develop means of solving problems they encounter on the farms in respect to their production. The Ekiti State cocoa farmers associations both in the state and in the local levels should see towards forums with researchers, NGOs, Extension agents, Input dealers on newly cocoa updates as these will apprise them better on various technologies and based them on pragmatic efforts in carrying out various technologies on cocoa; thereby, ensuring increase in production yearly.

\section{References}

[1] Adegeye A. J, (1997). Paper on production and Marketing of Cocoa in Nigeria: Problems and Solutions, pp: $1-10$. Agricultural Credit Guarantee Scheme Report, (2011).

[2] Ajayi, S. I and Oyejide T. A. (1974). The Role of Cocoa in Nigeria's Economic Development: In Kotey, R. A., C. Okali and Rourke B. E. (Eds). The Economics of Cocoa Economics Research Conference, Legon, Ghana, April 1973. 232, Pp: 206-230.

[3] Akinbola C. A. (2001). International Project on Cocoa Marketing and Trade in Nigeria. Manual on Cocoa Quality and Training Manual for Extension Workers. Pp: 10-24.

[4] Altalb, A. A. T., Filipek, T. and Skowron, P. (2015). The Role of Agricultural Extension in the Transfer and Adoption of Agricultural Technologies. Asian Journal of Agriculture and Food Sciences (ISSN: 2321 - 1571) Volume 03.

[5] Ayoola, G. R. (1990). "Technology Progress in Agriculture; Some Issues" in Conference proceeding, Nigerian Economic Society, Minna Nigeria. Pp. 205-223.

[6] Falusi, A. O. (2008). "Sustainable Agriculture in Sub-Saharan Africa: A Critical Look into the Constraints and Prospects "Being Paper Presented at IARSAF Conference, IITA, Ibadan.
[7] Feder, L., Just R. E. and Zilberman O. (1985). Adoption of Agricultural Innovation, in Developing Countries: A Survey. Economic Development and Cultural Change, 32 (2): 255-298.

[8] Folayan, J. A., Daramola, A. G. \& Oguntade, A. E. (2006). Structure and Performance Evaluation of Cocoa Marketing Institutions in South-Western Nigeria: An Economic Analysis. Journal of Food, Agriculture and Environment, 4 (2), 123-128.

[9] ICCO (2003). International Cocoa Organization's Quarterly Bulletin of Cocoa Statistics, www.icco.com/cocoa stat, retrieved on 23/07/10.

[10] Johnston, J. And Dinardo, J. (1997). Econometrics Methods. Fourth Edition. The McGraw-Hill Companies, Inc, New York.

[11] Lawal J. O. and Oluyole K. A. (2008). Factors Influencing Adoption of Research Results and Agricultural Technologies Among Cocoa Farming Households in Oyo State, Nigeria. Int. J. Sustain. Crop Prod. 3 (5): 10-12.

[12] Monu E. D. And Omole M. A. (1983). Adoption of Recommended Farm Practices by Nigerian Cocoa Farmers., Nigerian J. AgricExtn 1 (2), 45-53.

[13] National Population Commission, (2006) Census. Federal Republic of Nigeria, December, 2006.

[14] Nweke F. I. And Akorhe J. A. (1983). Determinants Of Adoption Of New Technologies Among Smallholders And Implication For Administration Of Transfer Programmes. Agricultural Administration. 12, 77-90.

[15] Oladosu, I. O. and. Yekinni O. T (2008) An Assessment of Agricultural Extension Activities to Cocoa Farmers in Ekiti West Local Government Area of Ekiti State International Journal of Agricultural Economics \& Rural Development - 1 (2): 2008@ IJAERD, 2008.

[16] Oluyole K. A., Egbetokun O. A., Oni O. A., andAigbekaen E. O. (2011) Technological Changes and Labour Demand among Cocoa Farmers in Nigeria 1 Cocoa Research Institute of Nigeria, P. M. B. 5244, Ibadan, NigeriaWorld Journal of Agricultural Sciences 7 (5): 638-641, 2011 ISSN 1817-3047 (C) IDOSI Publications, 2011.

[17] Opeke L. K. (1987). Tropical Tree crops. Ibadan: Spectrum Books Ltd., pp. 108-120.

[18] Uwatt B. U. (1997). Technology Agricultural Productivity and Food Security in Akwa- Ibom state, Nigeria: Interim Report, ARSSRAN, Winrock International, USA

[19] Wessel, M. and P. M. F. Quist-Wessel (2015). Cocoa production in West Africa, a review and analysis of recent developments, NJAS-Wageningen Journal of Life Sciences 74-75 (2015) 1-7.

[20] Wikipedia Online Encyclopedia, (2010), http://en.wikipedia.org/wiki/Talk:Ekiti State Retrieved on 20/08/2010.

[21] Wikipedia Online Encyclopedia, $\mathrm{http} / / / \mathrm{www}$.worldcocoafoundation.org/learn-about cocoa/documents/CocoaMarketUpdate as of 5.18.10.pdf. Retrieved 11 December 2011. 